\title{
PLANNING FEATURES OF SMALL UKRAINIAN SCHOOL SPACES BETWEEN XIX-XX CENTURIES
}

\author{
Mariia Veres \\ PhD student \\ Author's Orcid number: 0000-0002-3119-7905 \\ Kyiv National University of Construction and Architecture, Kyiv, Ukraine \\ Faculty of Architecture \\ Department of Architecture Theory
}

\section{ABSTRACT}

This article analyzes the planning features of small school spaces in different regions of Ukraine between the XIX - XX centuries. The main constructive decisions of typical residential architecture which manifested itself in school construction are identified. On the example of Ukraine, we trace a large number of stylistic and planning borrowings from typical residential architecture of the folk artists and architects from different regions, which manifested itself in rural school construction.

Key words: folk architecture, facades, structures, materials, spatial composition, typology, history. 


\section{INTRODUCTION}

In the late XIX - early XX centuries during the national upsurge of Ukraine, the most significant qualitative changes took place in the education system, design and construction of educational spaces. As the number of inhabitants in rural areas significantly exceeded the number of urban population, an urgent issue in providing educational space for the inhabitants of villages and towns arose.

The socio-political situation in the late XIX - early XX centuries was undoubtedly the main reason that became decisive for the formation of the typology of the folk architecture and, in particular, the functional and planning organization of architecture of rural schools. The developed solutions were efficient, constructive, economical, hygienic and energetic - thus, the maintenance of a building was very economic. This approach turned out to be decisive, it was a modern approach to the new situation, a radical solution to the critical situation of providing the country with educational spaces. The analysis of the planning organization in relation to the architectural context reveals innovative nature of the system of social architecture that it implemented.

In the late XIX - early XX centuries the characteristic feature of the folk architecture was widespread use of various local materials and structures, which led to decoration of facades and architectural design of buildings in general. The constructive solutions were defined to be as costeffective as possible, but they were also easy and quick to implement, as schools had to be built in a short period of time.

The methodology of research is based on a systematic and comprehensive approach and includes methods of analysis and synthesis of collected scientific data. Using the analysis of written and graphic sources connected with the history of the objects. A comparative analysis between school and residential architecture established the relationship of their planning features. Systematization of the obtained results reveals the main planning features which were used in the architecture of educational public buildings of Ukraine in the late XIX - early XIX centuries.

\section{PLANNING FEATURES OF SMALL UKRAINIAN SCHOOL SPACES}

At the end of the XIX and the beginning of the XX centuries, in Ukrainian villages mass cultural and household and housing construction began. Housing construction and construction of primary and secondary schools, kindergartens, nurseries, clubs, shops, canteens and other public buildings became widespread. In villages modern complexes of public centres, which included all the necessary cultural and household institutions, started appearing. Quite rapidly the architectural appearance of Ukrainian countryside changed. This stage was crucial for the evolution of the architecture of school buildings in Ukraine in rural areas and it became possible due to the growth of material and technical base of the regions, the accelerated increase of cultural level and material opportunities of rural population.

Functional planning organization of the folk architecture of rural schools of Ukraine is mainly due to the method that was the basis of folk construction, in which buildings in rural areas were built not according to the project, but according to the best standard samples that were typical for a particular region of Ukraine. Based on the peculiarities of the historical, political, geographical, cultural and socio-economic development of a region and the availability of certain building materials - there was development and formation of planning organization and stylistic processes considering stylistic, compositional regional features in accordance with the life of a particular locality. Neighbouring countries also had a significant influence on the formation of Ukrainian folk architecture. In public housing and school buildings in western regions of Ukraine there are common features with the architecture of neighbouring nations - Moldavia, Romania, Hungary, Czechoslovakia and Poland (Samoilovich, 1972, p.11).

An important role in the formation of planning organization, spatial composition, architectural and artistic decision in the folk architecture was played by the use of certain types of wall structures, which depended primarily on local building materials used for their construction. There are six main districts in accordance with the architectural and ethnographic zoning in Ukraine: 
1) Polissya - the main building material is wood;

2) the Carpathians (Prykarpattia, Zakarpattia, Bukovyna) - the main building material is wood;

3) Podillya - the main building materials are wood and clay;

4) Slobozhanshchyna, Poltava region - the main building materials are wood and clay;

5 ) the Middle Dnieper - the main building materials are clay, natural stone, wood;

6) the Lower Dnieper and the South - the main building materials are clay, natural stone.

The use of local materials led to different types of wall structures - in the North, the Carpathians, and in some areas of Slobozhanshchyna, Poltava, Kyiv, Podillya walls were built of woods, - in the forest-steppe zone they were mostly shell, - in the south mostly monolithic. This typology of structures is typical mainly for people's construction of Ukraine in the late XIX century. But in the early twentieth century with the shortage of timber, log house construction decreased, giving way to structures which used less wood.

The peculiarities of constructive solution of wall constructions influenced the appearance of buildings and their architecture. The following basic methods of constructive solution of walls in different regions of Ukraine were determined:

- wooden walls;

- shell walls;

- monolithic walls.

Table 1. Constructive solution of walls in different regions of Ukraine early XX centurie. Source: table made by author, Photos from free Internet resources

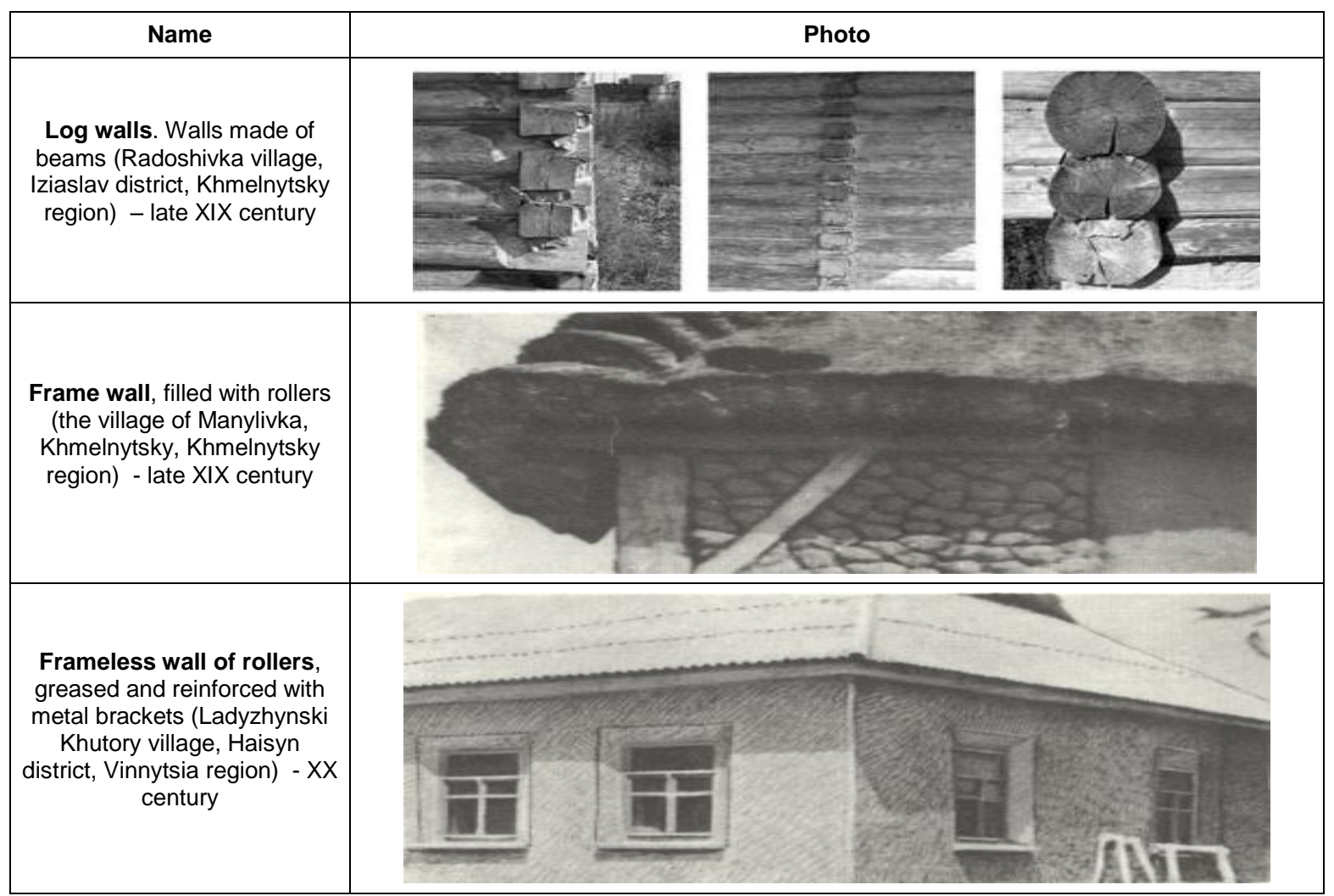




\begin{tabular}{|c|c|c|}
\hline Name & Photo \\
\hline $\begin{array}{c}\text { Monolithic wall made of } \\
\text { natural stone (Pylypy Borivski } \\
\text { village, Tomashpil district, } \\
\text { Vinnytsia region) - XX century }\end{array}$ & \\
\hline
\end{tabular}

The main materials used for wall structures were:

- wood (chopped walls were built of wooden logs (round timber), plates and bars, logs were used mainly in areas rich in forest);

- clay (adobe, clayolite, clay roll and adobe wall constructions);

- natural stone (mostly limestone); in the Southern areas: - mostly shell rock (in the form of sawn blocks, other types of natural stone - in the form of rubble); in Podillya and in the Western areas - dense limestone; stone walls, in most cases plastered, only in some areas the walls had natural texture of stone);

- chalk, marl and other building materials (typical for the South-Eastern regions of Ukraine) (Samoilovich, 1971, p. 23).

Table 2. Examples of small school buildings in different regions of Ukraine late XIX - ealy XX centuries. Source: table made by author, Photos from free Internet resources

\begin{tabular}{|c|c|c|c|}
\hline Name & Photo 1 \\
\hline $\begin{array}{c}\text { 1) School of the late } \\
\text { 19th century in the } \\
\text { village Lotasheve, } \\
\text { Talnivskyi district, } \\
\text { Cherkasy region; }\end{array}$ \\
$\begin{array}{c}\text { 2) Two-set school in } \\
\text { the village Davidivka, } \\
\text { early 20th century }\end{array}$ \\
\hline $\begin{array}{c}\text { 1) One-set school of } \\
\text { the Dnieper region; } \\
\text { 2) Rural one-set } \\
\text { school of Hrebinka } \\
\text { District }\end{array}$
\end{tabular}




\begin{tabular}{|c|c|c|}
\hline Name & Photo 1 & Photo 2 \\
\hline $\begin{array}{c}\text { 1) The building of a } \\
\text { seven-year school, } \\
\text { early 20th century; } \\
\text { 2) One-set school in } \\
\text { the village } \\
\text { Makushikha, } \\
\text { Chernihiv region. } \\
\text { Architect Opanas } \\
\text { Slastyon. }\end{array}$ & &
\end{tabular}

In the late XIX - early XX centuries a characteristic feature of the folk architecture was widespread use of various local materials and structures, which led to decoration of facades and architectural design of buildings in general. A characteristic feature of Ukrainian folk architecture is the extreme simplicity and conciseness of spatial composition. This feature is characteristic not only for residential buildings, but also school and public buildings.

The simplicity of spatial composition of the folk architecture is due to the simplicity of configuration of a building plan and building materials, which also required simple design solutions and architectural forms.

The symmetry of the spatial composition and the asymmetrical solution of facades were main characteristic features of Ukrainian folk architecture of the late XIX and early XX centuries. The symmetry of the total volume of public housing corresponds to and was logical development of symmetrical configuration of a plan. The asymmetry of the decision of facades was based on asymmetry of planning composition of national habitation as in these cases the most expedient organization of inhabited and auxiliary premises was created. Free, asymmetrical arrangement on facades of individual architectural elements, with the overall symmetrical volume of a house, created a special ease and at the same time aesthetic completeness, which was inherent in the best examples of the folk art.

In most cases, the folk architecture of Ukraine, depending on a region identifies the main compositional element that has significant and sometimes decisive influence on the general artistic solution of the folk architecture of a village:

- Eastern, North-Eastern areas - the main compositional element in architectural and artistic solution of housing is windows, which were always made with shutters in these areas;

- the left-bank part of the forest-steppe, the Carpathians - attics played a significant role in the architecture of public housing;

- Southern areas - the solution of gables of saddle roofs;

- in some areas the main emphasis is on the decorative finishing of large areas of walls of a house, in others the main thing is the solution of the roof, the allocation of the entrance to a house etc (Kosmina,1980, p.18).

According to the traditions and aesthetic preferences of the folk architects, which formed in different regions of Ukraine, certain architectural dominants were used in decoration of the folk architecture, the location of a house relative to the street was of great importance. Depending on the location of a building, architectural design of facades also changed. In some cases, the main facade was the one with the entrance to a house, in others - the one facing the street.

The architectural and artistic solution is based on the contrasting ratios of individual elements and details, or one part relative to the whole. This principle is characteristic for the creative method of the folk artists which can be traced in a variety of forms and means of decorative and artistic finishing of architectural elements. The use of a contrasting correlation of individual elements, or one of the elements and the whole, made it possible with minimal and simplest artistic means to achieve 
maximum expressiveness of the architectural image. A characteristic feature of the folk architecture of Ukraine is the commonality of the main compositional techniques and at the same time diversity of architectural solutions in different regions. This is also inherent in the planning of rural housing, its constructive solution.

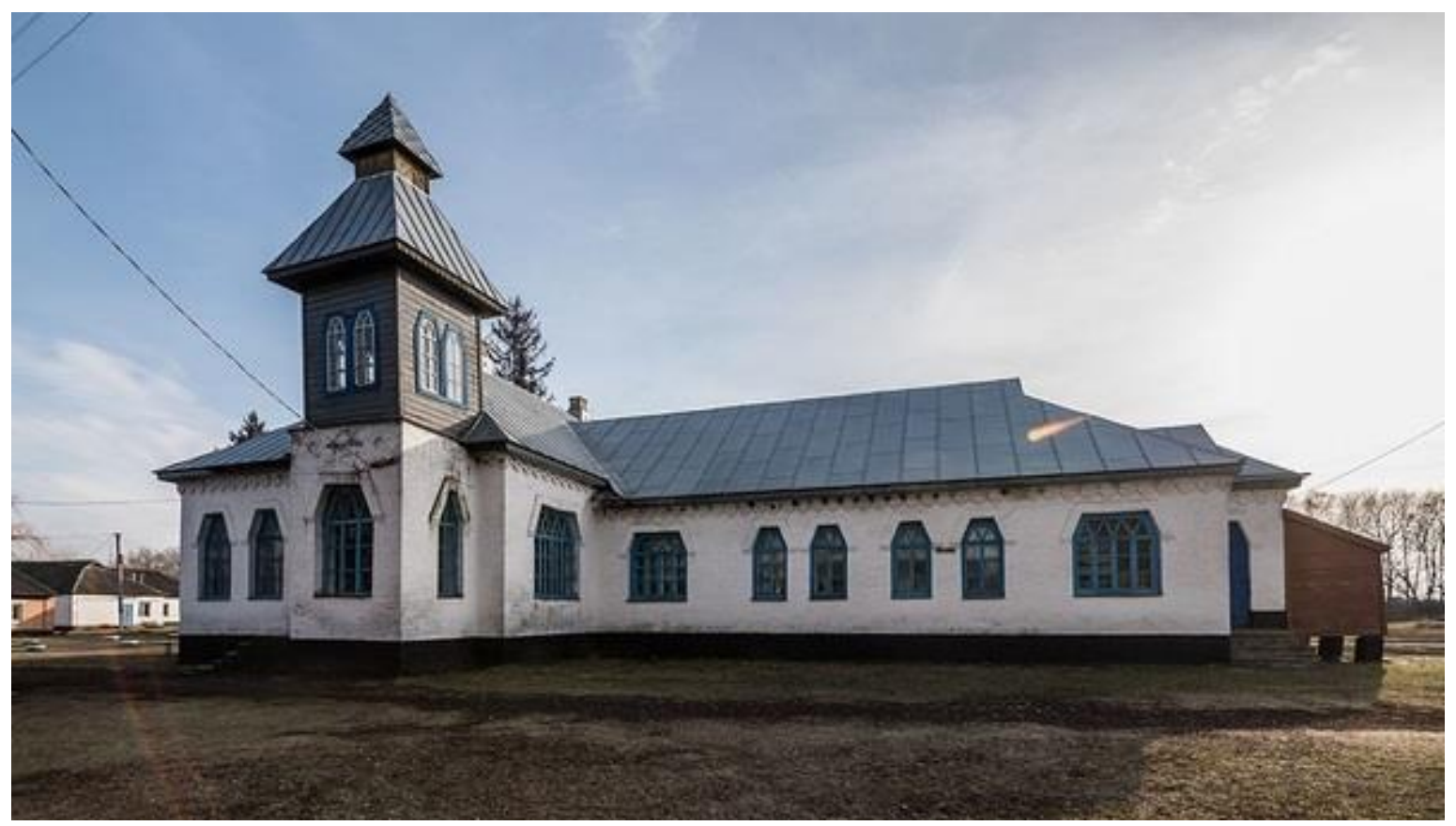

Fig. 1. Two-set rural school in the village Hiltsi Chornuhynskiy Poltava region. Source: Photos from free Internet resources

The typicality of the main structural features of the folk architecture is due to the continuous process of selection of all most relevant, economic, which is consistent with living conditions and aesthetic preferences of the people. With this typical compositional techniques of public housing there is no uniformity and pattern in the architectural solution, because in each case this decision along with common, typical for a region has individual, characteristic features that correspond to aesthetic tastes of their direct realiser. It is implied that individual features of the architectural solution not only in different regions, but also in different villages correspond to the folk artistic traditions developed by collective experience and collective creativity and do not contradict them.

The typicality of compositional techniques of the folk architecture is the basis of the architectural unity of a street and a settlement as a whole, and the diversity of variations of the architectural solution is the basis of the picturesqueness of this building. It is these features of the folk architecture that create the conditions for building a settlement in a single artistic ensemble. Peculiar features of rural housing, due to which the folk architecture of one district differs from another, can be quite clearly traced in the North, South and the central part of Ukraine. 


\section{CONCLUSIONS}

The analysis of planning features of small Ukrainian school spaces shown that at the end of the $X I X$ - beginning of the XX century, there was a sharp increase in sanitary and hygienic conditions, comfort of an apartment and degree of reliability and durability of buildings and structures, which created necessary conditions for a gradual reduction of cultural and domestic differences between urban and rural areas.

Despite traditional forms of folk construction, the architecture of the countryside was constantly changing. A feature of new housing construction in Ukraine in the late XIX - early XX century was organic combination of the best folk architectural and construction and artistic traditions with modern requirements for that time, which met the new conditions in the early twentieth century.

On the example of Ukraine, we trace a large number of stylistic and planning borrowings from typical residential architecture of the folk artists and architects from different regions, which manifested itself in school construction. The methodology, which was initiated in collective housing projects, was optimized in schools, setting up the modern system in its concept and premises, effective in its materialization and operation. Along with general national features which were inherent in the folk architecture, it had its own differences and peculiarities in each region and even settlement. It is also important to emphasize the commonality of the principles of general composition in projects of school buildings, and the neighbouring countries, which indicates the presence of common features in the architecture of housing of these nations.

In further research this article can serve the development of architectural planning of the educational environment in rural areas. The study of folk building and artistic traditions has not only theoretical but also practical significance. The factual and analytical materials presented in this article can be useful in modern design or in the restoration of historical architectural monuments of small schools.

\section{BIBLIOGRAPHY}

Aleksuk, A. et al. Public Education in the Ukrainian SSR (Kyiv 1970)

Bilen'kyi, I. Ukraïns'ki pryvatni shkoly v Halychyni (Lviv 1922)

Kolasky, J. Education in Soviet Ukraine: A Study in Discrimination and Russification (Toronto 1968).

Kosmina T.V. Silske zhytlo Podillia kinets XIX-XX st Istoryko etnohrafichne doslidzhennia (Kyiv 1980).

Marzeyev A. Zhilishcha y sanitarnyy byt sel'skogo naselennya Ukrainy, Khar'kov, 1927.

Rusov A.A, Opisaniye Chernigovskoy gubernni, t. II, Chernigov, 1899, (Dann'íe po Surozhskomu uyezlu na $1845 \mathrm{~g}$.)

Samoylovych V.P. Ukrayins'ke narodne zhytlo (kinets' KHIKH - pochatok KHKH st.) Akademiya nauk URSR/Instytut mystetstvoznavstva, fol'kloru ta etnohrafiyi im. M.T. Ryl's'koho/Muzey narodnoyi arkhitektury i pobutu Ukrayins'koyi RSR/ Kyyiv: Naukova dumka, 1972.

Samoylovych V.P., M. Solomonov. Y.U. Khokhol, Dim na vybir, K., 1971.

Samoylovich, V.P. Fundamenty, steny, peregorodki i perekrytiya $\vee$ maloetazhnykh zhilykh domakh/V.P. Samoylovich, Y. U. Khokhol. - K. : Gosstroyizdat USSR, 1961.

Tokarev S.A. Severoukrainskaya zkspeditsiya 1945 g. Institut ztnografni. Kratkiye soobshcheniya, II, 1947.

Wańczura, A. Szkolnictwo w Starej Rusi (Lviv 1923).

Zavoloka, M. Zahal'noosvitnia shkola Ukraïny v kin. XIX-poch. XX st. (Kyiv 1971). 


\section{AUTHOR'S NOTE}

Mariia Veres, Ph.D. student of the Department of Architecture Theory, Kyiv National University of Construction and Architecture. The main area of research: history of architecture, architecture of the XIX-XX centuries.

Contact | Kontakt: maryveresart@gmail.com 